\title{
Syntrophomonas cellicola sp. nov., a spore- forming syntrophic bacterium isolated from a distilled-spirit-fermenting cellar, and assignment of Syntrophospora bryantii to Syntrophomonas bryantii comb. nov.
}

\author{
Chenggang $\mathrm{Wu}^{1,2}$ Xiaoli Liu ${ }^{1}$ and Xiuzhu Dong ${ }^{1}$ \\ ${ }^{1}$ State Key Laboratory of Microbial Resources, Institute of Microbiology, Chinese Academy of \\ Sciences, Beijing 100080, P. R. China \\ ${ }^{2}$ Graduate School, Chinese Academy of Sciences, Beijing 100049, P. R. China
}

Correspondence
Xiuzhu Dong
dongxz@sun.im.ac.cn

Butyrate is an important intermediate in the anaerobic degradation of organic matter (Mackie \& Bryant, 1981) and has to be degraded by consortia of at least two trophic groups (syntrophic acetogenic bacteria and hydrogen scavengers) because of the unfavourable energetics of the reactions (Schink, 1997). Syntrophomonas wolfei subsp. wolfei (McInerney et al., 1979, 1981; Beaty \& McInerney, 1987) was the first described syntrophic bacterium that degraded butyrate in co-culture with methanogens or hydrogen-utilizing sulfate-reducing bacteria. Since then, Syntrophospora bryantii (Stieb \& Schink, 1985; Zhao et al., 1990), Syntrophomonas sapovorans (Roy et al., 1986), Syntrophomonas wolfei subsp. saponavida (Lorowitz et al., 1989), Thermosyntropha lipolytica (Svetlitshnyi et al., 1996), Syntrophus aciditrophicus (Jackson et al., 1999), Smithella

The GenBank/EMBL/DDBJ accession number for the 16S rRNA gene sequence of Syntrophomonas cellicola $19 \mathrm{~J}-3^{\top}$ is DQ288691. propionica (Liu et al., 1999), Syntrophothermus lipocalidus (Sekiguchi et al., 2000), Syntrophomonas curvata (Zhang et al., 2004) and Syntrophomonas erecta (Zhang et al., 2005) have been isolated and characterized. Recently, 'Syntrophomonas erecta subsp. sporosyntropha', which produced spores in co-culture with methanogens, was described (Wu et al., 2006). In this paper, we describe the isolation and characterization of a sporulated Syntrophomonas strain with Gram-positive cell-wall structure, strain $19 \mathrm{~J}-3^{\mathrm{T}}$, which was obtained from a distilledspirit-fermenting cellar in Hebei Province, China.

Methanobacterium formicicum DSM $1535^{\mathrm{T}}$ and Desulfovibrio strain G11 were kindly provided by Dr Alfons Stams (Department of Microbiology, Wageningen University, The Netherlands).

A pre-reduced basal medium described by McInerney et al. (1979) was used for isolation and routine cultivation. The 
gas phase was $\mathrm{N}_{2}$ gas $\left(1.01 \times 10^{5} \mathrm{~Pa}\right)$ except that Methanobacterium formicicum DSM $1535^{\mathrm{T}}$ was cultivated with $\mathrm{H}_{2} / \mathrm{CO}_{2}\left(80: 20,1.25 \times 10^{5} \mathrm{~Pa}\right)$. All inoculations and transfers were done with syringes and needles. Incubations were at $37^{\circ} \mathrm{C}$ and in dark unless indicated. The purity of co-cultures and pure cultures was examined periodically by monitoring the cell morphology under a bright-field microscope and the absence of growth in peptone-yeast extract-glucose (PYG) medium (Britz \& Tracey, 1983).

The procedures used to examine the morphology, nutrition and growth properties, to extract genomic DNA and to determine the $\mathrm{G}+\mathrm{C}$ content of the novel strain were those described by Zhang et al. (2005).

The 16S rRNA gene was amplified by PCR and sequenced using the method described by Weisburg et al. (1991). 16S rRNA gene sequences of strain 19J-3 ${ }^{\mathrm{T}}$ and reference strains in GenBank were aligned using CLUSTAL X program (version 1.83). Phylogenetic trees were constructed using UPGMA, minimum evolution and maximum-parsimony methods implemented in the MEGA3 program and the topology of the phylogenetic trees was evaluated by bootstrap analysis of 1000 datasets.

A sample from the walls of a distilled-spirit-fermenting cellar was inoculated into pre-reduced medium with $20 \mathrm{mM}$ butyrate to enrich for anaerobic butyrate-degrading consortia. After repeated roll-tube isolations (Hungate, 1969) in butyrate agar medium which contained a $5 \%(\mathrm{v} / \mathrm{v})$ culture of Methanobacterium formicicum DSM $1535^{\mathrm{T}}$ and $5 \%(\mathrm{v} / \mathrm{v})$ of the enrichment culture, a biculture producing methane from butyrate but not in PYG medium was obtained. This biculture formed brownish colonies of $0.6-1.0 \mathrm{~mm}$ in diameter in roll tubes and showed green fluorescence under $420 \mathrm{~nm}$ light. Only two kinds of cell morphologies were observed in the biculture, one was a straight Methanobacterium formicicum-like rod and the other was a slightly curved, spore-forming rod. To purify the sporeforming strain, the culture was pasteurized twice at $90{ }^{\circ} \mathrm{C}$ for $25 \mathrm{~min}$ and, after pasteurization, $0.5 \mathrm{ml}$ heated culture and $0.5 \mathrm{ml} \mathrm{H} / \mathrm{CO}_{2}$-grown Methanobacterium formicicum DSM $1535^{\mathrm{T}}$ were inoculated into butyrate-containing basal medium and incubated at $37^{\circ} \mathrm{C}$ until methane was detected. The monoculture of the butyrate-degrading syntrophic strain was purified by inoculating the biculture into medium with $20 \mathrm{mM}$ crotonate as sole substrate instead of butyrate and $10 \mathrm{mM}$ 2-bromoethanesulfonic acid to inhibit growth of the methanogen, and the isolate was designated as strain $19 \mathrm{~J}-3^{\mathrm{T}}$. When growing on crotonate agar medium in pure culture, tiny white colonies, $0 \cdot 2-0 \cdot 3 \mathrm{~mm}$ in diameter, were formed.

Cells of strain $19 \mathrm{~J}-3^{\mathrm{T}}$ were slightly curved rods with rounded ends, $0 \cdot 4-0 \cdot 5 \times 3 \cdot 0-10 \cdot 0 \mu \mathrm{m}$, occurring singly or in clumps. An oval spore was formed at the end of the cell (Fig. 1a) and poly- $\beta$-hydroxyalkanoate was accumulated (Fig. $1 \mathrm{~b}$ ), which was confirmed by cytochemical stain (Burdon, 1946).
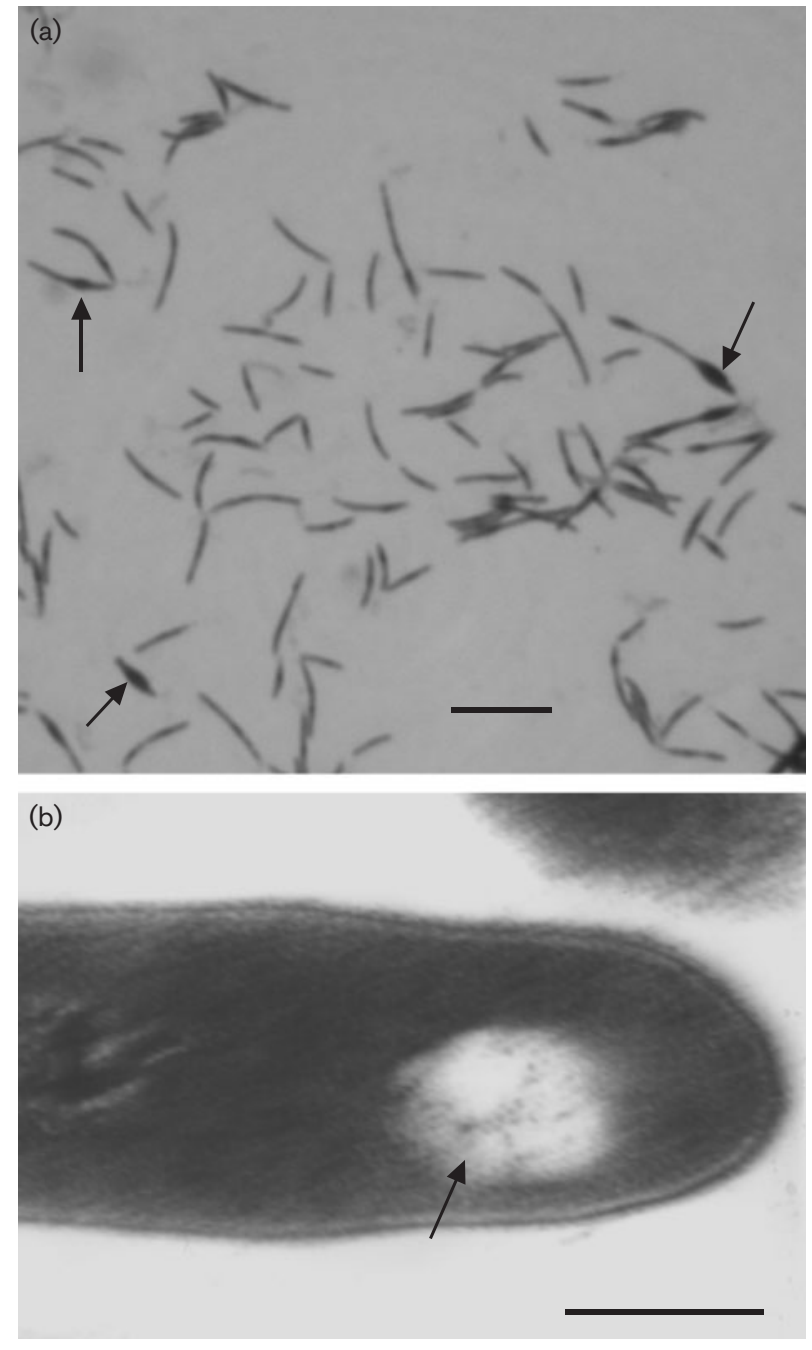

Fig. 1. Photomicrographs of cells of strain $19 \mathrm{~J}-3^{\top}$ grown in pure culture on crotonate. (a) Phase-contrast light micrograph. Arrows point to sporulated cells. Bar, $6 \mu \mathrm{m}$. (b) Electron micrograph of an ultrathin section showing the typical Gram-positive wall structure and the presence of poly- $\beta$-hydroxyalkanoate (PHA); the arrow indicates a PHA granule. Bar, $0.3 \mu \mathrm{m}$.

The Gram reaction was negative to weakly positive; however, a Gram-positive cell wall ultrastructure was observed in ultrathin sections of strain $19 \mathrm{~J}-3^{\mathrm{T}}$ (Fig. 1b). A single flagellum was inserted in the midpoint of the cell (not shown).

Strain $19 \mathrm{~J}-3^{\mathrm{T}}$ degraded $20 \mathrm{mM}$ butyrate into about $40 \mathrm{mM}$ acetate and $4.87 \mathrm{mM}$ methane within 14 days in co-culture with Methanobacterium formicicum DSM $1535^{\mathrm{T}}$ and degraded $20 \mathrm{mM}$ butyrate within 10.5 days in co-culture with Desulfovibrio strain G11. The strain neither grew nor produced methane on butyrate alone, whereas it degraded butyrate in an artificially constructed co-culture with Methanobacterium formicicum DSM $1535^{\mathrm{T}}$. Straight-chain fatty acids with four to nine carbons were degraded by cocultures of strain $19 \mathrm{~J}-3^{\mathrm{T}}$ with Methanobacterium formicicum 
DSM $1535^{\mathrm{T}}$ or Desulfovibrio strain G11; however, neither branched-chain fatty acids such as isobutyrate and isovalerate nor benzoate were degraded. Among the substrates used, fatty acids with even numbers of carbons were converted into acetate and $\mathrm{H}_{2}$, while those with odd numbers of carbons were converted into propionate, acetate and $\mathrm{H}_{2}$, implying that $\beta$-oxidation of fatty acids occurred. None of the following substrates were used by strain $19 \mathrm{~J}-3^{\mathrm{T}}$ as potential electron acceptors for butyrate degradation: sodium sulfate $(20 \mathrm{mM})$, sodium thiosulfate $(20 \mathrm{mM})$, sulfur $(20 \mathrm{mM})$, DMSO $(20 \mathrm{mM})$, sodium nitrate $(20 \mathrm{mM})$ and sodium fumarate $(20 \mathrm{mM})$.

Crotonate was the only compound tested that supported growth of strain $19 \mathrm{~J}-3^{\mathrm{T}}$ in pure culture, and $24.5 \mathrm{mM}$ crotonate was degraded to about $10.4 \mathrm{mM}$ butyrate and $23.3 \mathrm{mM}$ acetate in 4.5 days, with electron and carbon recoveries of $90 \cdot 0 \pm 1 \cdot 3 \%$ and $89 \cdot 4 \pm 1 \cdot 6 \%$, respectively. The doubling time of strain $19 \mathrm{~J}-3^{\mathrm{T}}$ was $6 \cdot 5 \mathrm{~h}$ when grown on $20 \mathrm{mM}$ crotonate at $37^{\circ} \mathrm{C}$. The molar growth yield of strain $19 \mathrm{~J}-3^{\mathrm{T}}$ with crotonate was $5 \cdot 0-5 \cdot 6 \mathrm{~g}$ dry weight $\mathrm{mol}^{-1}$. Growth and acid formation were not observed on the following substrates: yeast extract $(0.5 \%)$, tryptone $(1 \%)$, glucose $(20 \mathrm{mM})$, ribose $(20 \mathrm{mM})$, xylose $(20 \mathrm{mM})$, pyruvate $(20 \mathrm{mM})$ and fumarate $(20 \mathrm{mM})$.

The temperature range for growth of both the co-culture on butyrate and pure culture on crotonate was $25-45^{\circ} \mathrm{C}$, with optimal growth at $37-40^{\circ} \mathrm{C}$, and the $\mathrm{pH}$ for growth of both ranged from $6 \cdot 5$ to $8 \cdot 5$ with an optimal initial $\mathrm{pH}$ of $7 \cdot 0-7 \cdot 5$. The $\mathrm{NaCl}$ concentration range tolerated was $0-450 \mathrm{mM}$ (better growth below $100 \mathrm{mM}$ ). No growth was observed in air.

The $\mathrm{G}+\mathrm{C}$ content of the genomic DNA from strain 19J $-3^{\mathrm{T}}$ was determined as $48 \cdot 8 \mathrm{~mol} \%$.

A phylogenetic tree including strain $19 \mathrm{~J}-3^{\mathrm{T}}$ and other members of the family Syntrophomonadaceae was constructed (Fig. 2) based on a consensus length of 1421 bp of the 16S rRNA genes. Phylogenetically, strain $19 \mathrm{~J}-3^{\mathrm{T}}$ is most closely related to Syntrophospora bryantii DSM $3014^{\mathrm{T}}$
(94.3\% similarity) and Syntrophomonas wolfei subsp. wolfei DSM $2245^{\mathrm{T}}$ (93.6\% similarity), with $91 \cdot 8-94 \cdot 0 \%$ similarity to other Syntrophomonas species.

By a combination of phylogenetic relationships and phenotypic characteristics, strain $19 \mathrm{~J}-3^{\mathrm{T}}$ could represent a novel species of the genus Syntrophomonas. Morphologically, strain $19 \mathrm{~J}-3^{\mathrm{T}}$ formed spores in both co-culture and monoculture, while most other Syntrophomonas species did not form spores in the same medium and growth conditions. Comparison of substrate utilization patterns with those of other Syntrophomonas strains showed that strain $19 \mathrm{~J}-3^{\mathrm{T}}$ differed from Syntrophomonas wolfei subsp. saponavida DSM $4212^{\mathrm{T}}$, Syntrophomonas sapovorans DSM $3441^{\mathrm{T}}$ and Syntrophomonas curvata DSM $15682^{\mathrm{T}}$ by using only fatty acids with four to nine carbon atoms, from Syntrophomonas wolfei subsp. wolfei DSM $2245^{\mathrm{T}}$ by not using isoheptanoate and from Syntrophomonas erecta DSM $16215^{\mathrm{T}}$ and 'Syntrophomonas erecta subsp. sporosyntropha' by using pelargonate. Strain $19 \mathrm{~J}-3^{\mathrm{T}}$ differed from Syntrophospora bryantii by a difference of $11.2 \mathrm{~mol} \%$ in $\mathrm{G}+\mathrm{C}$ content and by not utilizing caprate, undecanoate or 2-methylbutyrate. Table 1 shows the characteristics of strain $19 \mathrm{~J}-3^{\mathrm{T}}$ that distinguish it from other taxa. Therefore, we propose strain $19 \mathrm{~J}-3^{\mathrm{T}}$ as the type strain of a novel species of the genus Syntrophomonas, Syntrophomonas cellicola sp. nov.

Clostridium bryantii was transferred to the new genus Syntrophospora by Zhao et al. (1990) on the basis of sporulation and the presence of a Gram-positive cell-wall ultrastructure, which differentiated it from Syntrophomonas wolfei subsp. wolfei, a non-spore-former with a Gramnegative cell wall ultrastructure. Although Syntrophomonas species possess a complex cell-wall ultrastructure indicative of a Gram-negative cell wall, the lack of lipopolysaccharides confirms their Gram-positive cell-wall structure. The recently completed genome sequence of Syntrophomonas wolfei subsp. wolfei DSM $2245^{\mathrm{T}}$ (http://genome.ornl.gov/ microbial/swol/) showed the presence of sporulationspecific genes in the genome, such as spo0A, a master regulator in bacterial sporulation found exclusively in sporeforming bacteria (Brown et al., 1994). We found that all

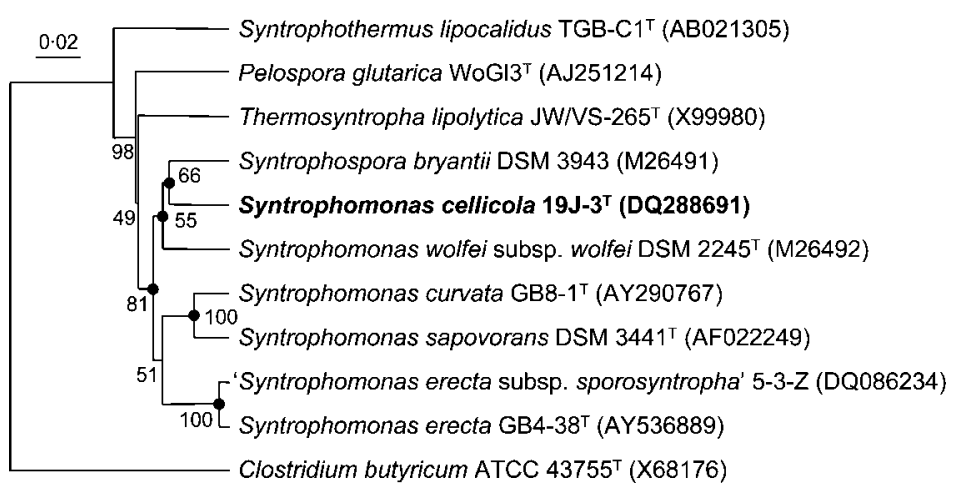

Fig. 2. Phylogenetic tree of strain $19 \mathrm{~J}-3^{\top}$ and related organisms based on a $1421 \mathrm{bp}$ fragment of the $16 \mathrm{~S}$ rRNA gene. The tree was rooted with the sequence from Clostridium butyricum ATCC $43755^{\top}$ and was constructed by using the UPGMA method. Solid circles indicate that the corresponding nodes (groups) are also recovered in minimum evolution and maximum-parsimony methods. Numbers at nodes represent percentage levels of bootstrap support based on the UPGMA method of 1000 resampled datasets. GenBank accession numbers are given in parentheses. Bar, $2 \%$ sequence divergence. 
Table 1. Characteristics of strain $19 \mathrm{~J}-3^{\top}$ and other mesophilic syntrophic bacteria in the family Syntrophomonadaceae

Strains: 1, Syntrophomonas cellicola sp. nov. 19J-3 $3^{\mathrm{T}}$; 2, Syntrophomonas wolfei subsp. wolfei DSM $2245^{\mathrm{T}}$ (unless indicated, data from McInerney et al., 1979, 1981; Beaty \& McInerney, 1987); 3, Syntrophospora bryantii DSM 3014 ${ }^{\mathrm{T}}$ (Stieb \& Schink, 1985; Zhao et al., 1990); 4, Syntrophomonas sapovorans DSM $3441^{\mathrm{T}}$ (Roy et al., 1986); 5, Syntrophomonas curvata DSM 15682 ${ }^{\mathrm{T}}$ (Zhang et al., 2004); 6, Syntrophomonas erecta DSM $16215^{\mathrm{T}}$ (Zhang et al., 2005); 7, 'Syntrophomonas erecta subsp. sporosyntropha' JCM 13344 (Wu et al., 2006); 8, Syntrophomonas wolfei subsp. saponavida DSM $4212^{\mathrm{T}}$ (Lorowitz et al., 1989). ND, No data available. All strains are positive for metabolism of butyrate to caprylate in co-culture with methanogens.

\begin{tabular}{|c|c|c|c|c|c|c|c|c|}
\hline Characteristic & 1 & 2 & 3 & 4 & 5 & 6 & 7 & 8 \\
\hline Cell width $(\mu \mathrm{m})$ & $0 \cdot 4-0 \cdot 5$ & $0 \cdot 5-1 \cdot 0$ & $0 \cdot 4$ & $0 \cdot 5$ & $0 \cdot 5-0 \cdot 7$ & $0 \cdot 6-0 \cdot 9$ & $0 \cdot 5-0 \cdot 7$ & $0 \cdot 4-0 \cdot 6$ \\
\hline Cell length $(\mu \mathrm{m})$ & $3 \cdot 0-10 \cdot 0$ & $2 \cdot 0-7 \cdot 0$ & $3 \cdot 0-6 \cdot 0$ & $2 \cdot 5$ & $2 \cdot 3-4 \cdot 0$ & $2 \cdot 0-8 \cdot 0$ & $4-14$ & $2 \cdot 0-4 \cdot 0$ \\
\hline Gram type & + & - & + & - & - & - & - & - \\
\hline Flagella & 1 & $2-8$ & 0 & $2-?$ & $1-3$ & $2-5$ & 0 & $2-4$ \\
\hline DNA G $+C$ content $(\mathrm{mol} \%)$ & $48 \cdot 8$ & $45 \cdot 1^{\star}$ & $37 \cdot 6$ & $\mathrm{ND}$ & $46 \cdot 6$ & $43 \cdot 2$ & $40 \cdot 6$ & $\mathrm{ND}$ \\
\hline Optimum pH & $7 \cdot 0-7 \cdot 5$ & $\mathrm{ND}$ & $6 \cdot 6-7 \cdot 5$ & $7 \cdot 3$ & $7 \cdot 5$ & $7 \cdot 8$ & $7 \cdot 0$ & $\mathrm{ND}$ \\
\hline Optimum temperature $\left({ }^{\circ} \mathrm{C}\right)$ & $37-40$ & $35-37$ & $28-34$ & $25-45$ & $35-37$ & $37-40$ & $37-40$ & ND \\
\hline \multicolumn{9}{|l|}{ Spore formation } \\
\hline Co-culture & + & - & + & - & - & - & + & - \\
\hline Monoculture & + & - & + & - & - & - & - & - \\
\hline \multicolumn{9}{|c|}{ Substrate utilization in co-culture with methanogens } \\
\hline 2-Methylbutyrate & - & - & + & - & - & - & - & - \\
\hline Pelargonate & + & $\mathrm{ND}$ & + & + & + & - & - & + \\
\hline Caprate & - & $\mathrm{ND}$ & + & + & + & - & - & + \\
\hline Undecanoate & - & $\mathrm{ND}$ & + & + & + & - & - & + \\
\hline Laurate & - & - & - & + & + & - & - & + \\
\hline Myristate & - & - & - & + & + & - & - & + \\
\hline Isoheptanoate & - & + & - & - & - & - & - & - \\
\hline
\end{tabular}

${ }^{\star}$ Data from Zhang et al. (2004).

recognized species of the genus Syntrophomonas contain a homologue of the spoOA gene of Clostridium and Bacillus species (C. Wu, X. Liu and X. Dong, unpublished data). Furthermore, sporulating Syntrophomonas strains were reported recently (Wu et al., 2006). Therefore, Syntrophomonas species all have the potential to form spores, which is in agreement with their phylogenetic placement within the low-G $+\mathrm{C}$-content Gram-positive bacteria. The inability to detect sporulation with previously isolated Syntrophomonas strains is probably due to the lack of suitable culture conditions. There is growing recognition that sporulation per se is not necessarily a good indicator of relatedness (Cook et al., 1991; Farrow et al., 1995). In addition, Collins et al. (1994) proposed to merge the genera Syntrophospora and Syntrophomonas, as the level of evolutionary divergence between Syntrophospora bryantii and Syntrophomonas wolfei subsp. wolfei was only about $6 \%$. Therefore, we propose to assign Syntrophospora bryantii to the genus Syntrophomonas as Syntrophomonas bryantii comb. nov.

\section{Emended description of the genus Syntrophomonas Mclnerney et al. 1982}

The genus description is the same as that given by Lorowitz et al. (1989) except that some strains form spores in co-culture with methanogens on fatty acids or in pure culture on crotonate. Isolated from anaerobic environments such as aquatic sediments, digester sludge, rumen digest, rice field mud and shallow marine sediments.

\section{Description of Syntrophomonas cellicola sp. nov.}

Syntrophomonas cellicola (cel.li.co'la. L. n. cella a storeroom for wine and food; L. suff. - cola from L. n. incola an inhabitant, dweller; N.L. n. cellicola an inhabitant of a storeroom, indicating that the type strain was originally isolated from a distilled-spirit-fermenting cellar).

Cells are Gram-variable, slightly curved rods, $0 \cdot 4-0.5 \times 4-7 \mu \mathrm{m}$, spore-forming and with one laterally inserted flagellum. The type strain grows in pure culture only on crotonate. In syntrophic association with Methanobacterium formicicum DSM $1535^{\mathrm{T}}$ or Desulfovibrio strain G11, the organism uses saturated fatty acids with four to nine carbon atoms by $\beta$-oxidation. Cells grow between 25 and $45^{\circ} \mathrm{C}$ (optimum $37^{\circ} \mathrm{C}$ ) and at $\mathrm{pH} 6 \cdot 5-8 \cdot 5$ (optimum $\mathrm{pH} 7 \cdot 0-7 \cdot 5)$. The genomic DNA G $+\mathrm{C}$ content is $48 \cdot 8 \mathrm{~mol} \%$.

The type strain is $19 \mathrm{~J}-3^{\mathrm{T}}$ (=CGMCC $1.5041^{\mathrm{T}}=\mathrm{JCM}$ $13582^{\mathrm{T}}$ ), isolated from a distilled-spirit-fermenting cellar in Hebei Province, China. 


\section{Description of Syntrophomonas bryantii comb. nov.}

Basonym: Clostridium bryantii Stieb and Schink 1985.

The description of Syntrophomonas bryantii is that given for Syntrophospora bryantii by Zhao et al. (1990). The type strain is strain $\mathrm{CuCal}^{\mathrm{T}}\left[=\mathrm{DSM} 3014 \mathrm{~A}^{\mathrm{T}}\right.$ (co-culture with Desulfovibrio sp. E70) $=\mathrm{DSM} 3014 \mathrm{~B}^{\mathrm{T}}$ (co-culture with Methanospirillum hungatei M1h)].

\section{Acknowledgements}

This work has been supported by the National Nature Science Foundation of China under grant no. 30025001.

\section{References}

Beaty, P. S. \& Mclnerney, M. J. (1987). Growth of Syntrophomonas wolfei in pure culture on crotonate. Arch Microbiol 147, 389-393.

Britz, T. J. \& Tracey, R. P. (1983). Isolation and characterization of red-pigmented Arachnia species from Salmonella enrichment selenite broth. FEMS Microbiol Lett 18, 239-243.

Brown, D. P., Genova-Raeva, L., Green, B. D., Wilkinson, S. R., Young, M. \& Youngman, P. (1994). Characterization of spo0A homologs in diverse Bacillus and Clostridium species identifies DNA binding domain. Mol Microbiol 14, 411-426.

Burdon, K. L. (1946). Fatty material in bacteria and fungi revealed by staining dried, fixed slide preparations. J Bacteriol 52, 665-678.

Collins, M. D., Lawson, P. A., Willems, A., Cordoba, J. J., FernandezGarayzabal, J., Garcia, P., Cai, J., Hippe, H. \& Farrow, J. A. E. (1994). The phylogeny of the genus Clostridium: proposal of five new genera and eleven new species combinations. Int J Syst Bacteriol 44, 812-826.

Cook, G. M., Janssen, P. H. \& Morgan, H. W. (1991). Endospore formation by Thermoanaerobium brockii HTD4. Syst Appl Microbiol 14, 240-244.

Farrow, J. A. E., Lawson, P. A., Hippe, H., Gauglitz, U. \& Collins, M. D. (1995). Phylogenetic evidence that the gram-negative nonsporulating bacterium Tissierella (Bacteroides) praeacuta is a member of the Clostridium subphylum of the gram-positive bacteria and description of Tissierella creatinini sp. nov. Int J Syst Bacteriol 45, 436-440.

Hungate, R. E. (1969). A roll tube method for cultivation of strict anaerobes. Methods Microbiol 3B, 117-132.

Jackson, B. E., Bhupathiraju, V. K., Tanner, R. S., Woese, C. R. \& Mclnerney, M. J. (1999). Syntrophus aciditrophicus sp. nov., a new anaerobic bacterium that degrades fatty acids and benzoate in syntrophic association with hydrogen-using microorganisms. Arch Microbiol 171, 107-114.

Liu, Y., Balkwill, D. L., Aldrich, H. C., Drake, G. R. \& Boone, D. R. (1999). Characterization of the anaerobic propionate-degrading syntrophs
Smithella propionica gen. nov., sp. nov. and Syntrophobacter wolinii. Int J Syst Bacteriol 49, 545-556.

Lorowitz, W. H., Zhao, H. \& Bryant, M. P. (1989). Syntrophomonas wolfei subsp. saponavida subsp. nov., a long-chain-fatty-aciddegrading, anaerobic syntrophic bacterium; Syntrophomonas wolfei subsp. wolfei subsp. nov.; and emended descriptions of the genus and species. Int J Syst Bacteriol 39, 122-126.

Mackie, R. I. \& Bryant, M. P. (1981). Metabolic activity of fatty acidoxidizing bacteria and the contribution of acetate, propionate, and butyrate, and $\mathrm{CO}_{2}$ to methanogenesis in cattle waste at 40 and $60^{\circ} \mathrm{C}$. Appl Environ Microbiol 41, 1363-1373.

Mclnerney, M. J., Bryant, M. P. \& Pfennig, N. (1979). Anaerobic bacterium that degrades fatty acids in syntrophic association with methanogens. Arch Microbiol 122, 129-135.

McInerney, M. J., Bryant, M. P., Hespell, R. B. \& Costerton, J. W. (1981). Syntrophomonas wolfei gen. nov. sp. nov., an anaerobic, syntrophic, fatty acid-oxidizing bacterium. Appl Environ Microbiol 41, 1029-1039.

Roy, F., Samain, E., Dubourguier, H. \& Albagnac, G. (1986). Syntrophomonas sapovorans sp. nov., a new obligately proton reducing anaerobe oxidizing saturated and unsaturated long chain fatty acids. Arch Microbiol 145, 142-147.

Schink, B. (1997). Energetics of syntrophic cooperation in methanogenic degradation. Mol Biol Rev 61, 262-280.

Sekiguchi, Y., Kamagata, Y., Nakamura, K., Ohashi, A. \& Harada, H. (2000). Syntrophothermus lipocalidus gen. nov., sp. nov., a novel thermophilic, syntrophic, fatty-acid-oxidizing anaerobe which utilizes isobutyrate. Int J Syst Evol Microbiol 50, 771-779.

Stieb, M. \& Schink, B. (1985). Anaerobic oxidation of fatty acids by Clostridium bryantii sp. nov., a sporeforming, obligately syntrophic bacterium. Arch Microbiol 140, 387-390.

Svetlitshnyi, V., Rainey, F. \& Wiegel, J. (1996). Thermosyntropha lipolytica gen. nov., sp. nov., a lipolytic, anaerobic, alkalitolerant, thermophilic bacterium utilizing short- and long-chain fatty acids in syntrophic coculture with a methanogenic archaeum. Int J Syst Bacteriol 46, 1131-1137.

Weisburg, W. G., Barn, S. M., Pelletier, D. A. \& Lane, D. J. (1991). 16 S ribosomal DNA amplification for phylogenetic study. J Bacteriol 173, 697-703.

Wu, C., Liu, X. \& Dong, X. (2006). Syntrophomonas erecta subsp. sporosyntropha subsp. nov., a spore-forming bacterium that degrades short chain fatty acids in co-culture with methanogens. Syst Appl Microbiol 29, 457-462.

Zhang, C., Liu, X. \& Dong, X. (2004). Syntrophomonas curvata sp. nov., an anaerobe that degrades fatty acids in co-culture with methanogens. Int J Syst Evol Microbiol 54, 969-973.

Zhang, C., Liu, X. \& Dong, X. (2005). Syntrophomonas erecta sp. nov., an novel anaerobe that syntrophically degrades short-chain fatty acids. Int J Syst Evol Microbiol 55, 799-803.

Zhao, H., Yang, D., Woese, C. R. \& Bryant, M. P. (1990). Assignment of Clostridium bryantii to Syntrophospora bryantii gen. nov., comb. nov. on the basis of a $16 \mathrm{~S}$ rRNA sequence analysis of its crotonategrown pure culture. Int J Syst Bacteriol 40, 40-44. 